\title{
Gode vevsprøver ved prostatakreft
}

\section{Ved hurtig nedfrysing av et tynt snitt fra prostatakjertelen kan vevsprøvene brukes til studier av genuttrykk og metabolisme.}

Prøver fra kreftsvulster undersøkes ikke lenger bare histologisk. Forskere studerer faktorer som gensammensetning, genuttrykk, proteinsammensetning og metabolitter fordi disse kan påvirke pasientens prognose. De tradisjonelle formalinfikserte parafinsnittene er ikke alltid egnet.

- Det finnes per i dag ikke noen allmenn enighet om hvordan man kan best samle ferske vevsprøver for å kunne forstå sykdomsutviklingen hos enkeltpasienten, sier Helena Bertilsson. Hun har i sin avhandling sett på faktorer som påvirker vevsprøvekvaliteten og har utviklet en protokoll for å høste gode vevsprøver fra pasienter som er operert for prostatakreft.

- Vi har laget en rask og enkel metode som bevarer vevet bedre gjennom rask nedfrysing av tynne vevsskiver, forteller hun. - Med vår nye metode lagres det ferske vevet slik at det enkelt kan studeres. Man kan vite eksakt hvilke typer celler det er i prøven man tar, og man analysere ikke bare gener, men også proteiner og metabolitter.

Bertilsson har brukt den nyutviklede teknikken til å studere sammenhengen mellom genuttrykk og nivået av metabolitter.

- Vi vet allerede at nivået av metabolitten sitrat er lavere i prostatakreftceller, mens kolinnivået er høyere. Det vi ikke vet så mye om, er hvorfor. I vår studie fant vi flere gener som korrelerte med lave nivåer av sitrat og høye nivåer av kolin. Disse genene har blant annet en sentral rolle ved nydanning av fettsyrer, hvilket er en viktig prosess for kreftceller i rask deling, avslutter Bertilsson.

\section{Kristin Viste}

kristin.viste@legeforeningen.no

Tidsskriftet

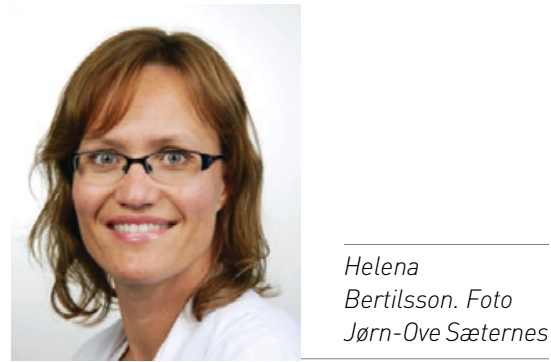

Disputas

Helena Bertilsson disputerte for ph.d.-graden ved Norges teknisk-naturvitenskapelige universitet 21.9. 2012. Tittelen på avhandlingen er Prostate cancer - translational research. optimizing tissue sampling suitable for histopathologic, transciptomic and metabolic profiling.

\section{Genetiske årsaker til medfødt døvhet}

\section{Genetiske undersøkelser kan identifisere årsaken til medfødt døvhet. Barn med medfødt døvhet har god effekt av cochleaimplantat.}

Det fødes ca. 30 døve barn i Norge hvert år. $95 \%$ av dem får tilbud om cochleaimplantat, et teknisk hjelpemiddel som opereres inn i det indre øre og gir døve muligheten til å høre lyd og oppfatte tale. De fleste døve barn har foreldre med normal hørsel.

- Målet for arbeidet vårt har vært å finne årsaken til døvhet hos barna som får operert inn cochleaimplantat. Vi antar at over $50 \%$ av tilfellene av medfødt døvhet skyldes arvelige faktorer. Det er viktig å kjenne årsaken til døvheten, både for valg av behandling og for å kunne gi genetisk veiledning til familiene. Derfor har vi vært spesielt interessert i å se på genetiske forandringer som forekommer hos disse barna og å identifisere barn som har syndromer hvor døvhet kan være det eneste symptomet, sier Geir Siem.

Studiene inkluderte 233 barn som fikk cochleaimplantat i perioden 1992-2005, i alt 215 familier. Siem har sett etter forandringer i de vanligste genene som er assosiert med døvhet og fant en genetisk årsak til døvheten hos $46 \%$ av barna. En liten undergruppe $(2,9 \%)$ hadde det potensielt dødelige Jervell og Lange-Nielsen syndrom, en sjelden arvelig tilstand med både døvhet og hjertearytmi.

- Forandringer i GJB2-genet, også kalt connexin 26, forekommer hyppig. Forandringer i SLC26A4-genet, også kalt pendrin, forekommer hyppig blant barn med misdannelser i det indre øre. Disse har god nytte av cochleaimplantat, sier Siem.

- Cochleaimplantasjon hos barn med Jervell og Lange-Nielsens syndrom kan utføres uten komplikasjoner og med gode resultater når det tas nødvendige forholdsregler. EKGundersøkelse er et godt verktøy for å identifisere barn med dette syndromet, sier Siem.

anneforus@hotmail.com

Tidsskriftet

\section{Anne Forus}

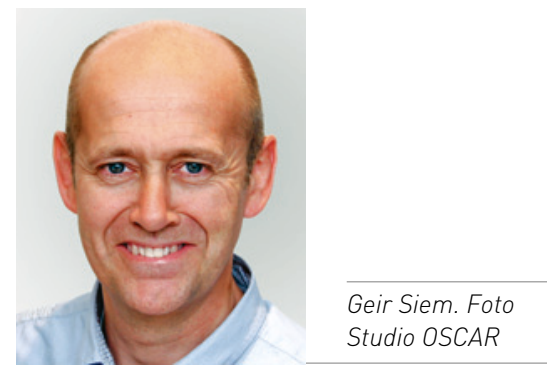

Disputas

Geir Siem disputerte for ph.d.-graden ved Universitetet i Oslo 28.9. 2012. Tittelen på avhandlingen er Pediatric cochlear implantation in Norway. A study of etiologies and outcomes, based on clinical and genetic studies. 